\title{
Mass sedimentation of Phaeocystis pouchetii in the Barents Sea
}

\author{
Paul Wassmann ${ }^{1}$, Maria Vernet ${ }^{2}$, B. Greg Mitchell ${ }^{2}$, Francisco Rey ${ }^{3}$ \\ ${ }^{1}$ Norwegian College of Fishery Science, University of Tromsø, PO Box 3083, Guleng, N-9001 Tromse, Norway \\ ${ }^{2}$ Marine Research Division, A-018, Scripps Institution of Oceanography, University of California, San Diego, La Jolla, \\ California 92093, USA \\ ${ }^{3}$ Institute for Marine Research, PO Box 1870, N-5024 Bergen, Norway
}

\begin{abstract}
Mass sedimentation of gelatinous colonies of the prymensiophyte Phaeocystis pouchetii were observed in the upper $100 \mathrm{~m}$ of Atlantic water in the central Barents Sea. Sedimentation rates of particulate organic carbon and nitrogen as well as pigments were the highest recorded so far from oceanic environments of the North Atlantic or coastal areas of Norway. High relative concentrations of phytoplankton pigments found in the traps are interpreted as a combination of sinking of intact phytoplankton cells and undegraded pigments present in macrozooplankton faecal pellets. Evidence presented in this study implies that the zooplankton community of the Barents Sea was not able to control this phytoplankton spring bloom. The suspended and sedimenting organic matter was rich in carbon and pigments, but poor in nitrogen. This is explained by the presence of large amounts of carbon-rich mucilage which $P$. pouchetii colonies develop during their development. In addition to diatoms, sedimentation of a gelatinous phytoplankton species like $P$. pouchetii may contribute significantly to the formation of marine snow and vertical flux from the euphotic zone. However, degradation of $P$. pouchetii derived detritus at depths less than $100 \mathrm{~m}$ greatly diminishes the likely significance of $P$. pouchetii blooms in processes such as the carbon flux to the deep ocean and sequestering of $\mathrm{CO}_{2}$.
\end{abstract}

\section{INTRODUCTION}

Mass occurrences of the colony-forming, planktonic, prymensiophyte algae Phaeocystis pouchetii have been reported since the last century (Lagerheim 1896, Gran 1902). P. pouchetii is described as a eurythermal, stenohaline species, with bipolar distribution. The species develops regular blooms in polar, subpolar and boreal waters (Kashkin 1963, Lancelot et al. 1987). There is usually one bloom episode per year and $P$. pouchetii may, according to Bigelow (1926), be the only organism that rivals diatoms in abundance during the vernal bloom. In the North Sea Phaeocystis blooms usually appear after diatom blooms and may reach chlorophyll a concentrations of $>20 \mathrm{mg} \mathrm{m}^{-3}$, with daily production ranging from 1 to $4.8 \mathrm{~g} \mathrm{C} \mathrm{m}^{-2}$ (Cadée \& Hegemann 1986, Gieskes \& Kraay 1977, Bätje \& Michaelis 1986, Veldhuis et al. 1986). Up to $60 \%$ of total fixed carbon has been found to be due to $P$. pouchetii during blooms (Guillard \& Hellebust 1971, Lancelot 1983, Eberlein et al. 1985). During blooms the numerical abundance in Norwegian coastal waters can vary between 40 and $83 \%$ of the standing crop (Sak- shaug 1972, Haug et al. 1973, Eilertsen et al. 1981, Hegseth 1982).

Phaeocystis pouchetii is also prominent in the marginal ice-edge zone and the open waters of the Barents Sea, where blooms of $P$. pouchetii, as a general rule, follow a diatom bloom in late spring (Rey \& Loeng 1985). However, at individual stations and during some years $P$. pouchetii may dominate the entire spring bloom in the Barents Sea (F. Rey unpubl.) and the Greenland Sea (L. Codispoti pers. comm.) P. pouchetii has been characterised as a causative agent responsible for the reduction of diatom populations (Smayda 1973, Barnard et al. 1984). The impact of a single species like $P$. pouchetii on the marine food web of areas like the North Sea and the Barents Sea is obviously considerable (Joiris et al. 1982, Rey \& Loeng 1985, Lancelot et al. 1987).

Disappearance of Phaeocystis pouchetii, as for any other blooms in boreal and arctic waters, could be caused by grazing, autolysis, microbial degradation or sedimentation. An antagonistic nature of $P$. pouchetii to other trophic levels has been suggested (Savage 1932, Zenkievitch 1963, Martens 1981. Schnack et al. 1984). 
$P$. pouchetii has, however, recently been characterised as food for copepods (Weisse 1983. Sargent et al. 1985. Tande \& Båmstedt 1987) and was actually preferred when offered simultaneously with diatoms (Huntley et al. 1987). These contradictory lines of evidence imply that grazing is likely to contribute to, but not cause, the disappearance of P. pouchetii blooms.

Autolysis and bacterial degradation have been suggested as important mechanisms for the disappearance of senescent P. pouchetii (Guillard \& Hellbust 1971 , Lancelot 1984, Lancelot et al. 1987). A significant fraction of the carbohydrate-rich, gelatinous material of older colonies of $P$. pouchetii is regarded as a rich substrate for bacteria (Veldhuis \& Admiraal 1985, Davidson \& Marchant 1987).

The life cycle of Phaeocystis pouchetii (flagellated and colonial stages), the large amounts of accumulated DOC, and heavy bacterial colonisation of suspended and sedimenting detritus of $P$. pouchetii suggests that $P$. pouchetii biomass is easily recycled in the upper part of the water column (F. Thingstad pers. comm.). Previous investigations have demonstrated positive buoyancy of $P$. pouchetii (Skreslett 1988), implying that sedimentation may be unimportant for this species. Data presented here, however, indicate that sedimentation of massive blooms of $P$. pouchetii may dominate its disappearance in late spring in the Barents Sea.

\section{MATERIAL AND METHODS}

Data were collected in May/June 1987 during PRO MARE Cruise 12 on board RV 'G. O. Sars' at 2 locations: Station I $\left(75^{\circ} 00^{\prime} \mathrm{N}, 28^{\circ} 37^{\prime} \mathrm{E}_{\text {; }}\right.$ Cruise stns 937,947 and $987 ; z=320 \mathrm{~m})$ and Station II $\left(74^{\circ} 29^{\prime} \mathrm{N}, 31^{\circ} 31^{\prime} \mathrm{E}\right.$; Cruise stns 894, 941 and $994 ; z=230 \mathrm{~m}$ ) in the central Barents Sea (Fig. 1). Station I was in an area dominated by Atlantic water, while Station II was in the vicinity of the Polar Front, which separates Atlantic from Polar water. Each location was visited 3 times at 11 and $17 \mathrm{~d}$ intervals for Stations I and II, respectively. Hydrographic profiles were obtained with a Neil Brown Mk III CTD-profiler mounted with a General Oceanic Rosette Sampler equipped with 51 Niskin bottles. Sampling depths were selected on the basis of salinity, temperature and in vivo fluorescence (Sea Tech) at the end of the downward cast.

Samples for nutrient analysis (nitrate/nitrite, phosphate, silicate, ammonia) and suspended biomass (particulate organic carbon and nitrogen (POC, PON) and pigments) were collected at 15 to 24 depths. Samples for nutrients were analysed on board with an autoanalyser, using standard methods (Føyn et al. 1981). Duplicate samples for the analysis of suspended POC and PON were filtered onto Whatman GF/F filters and

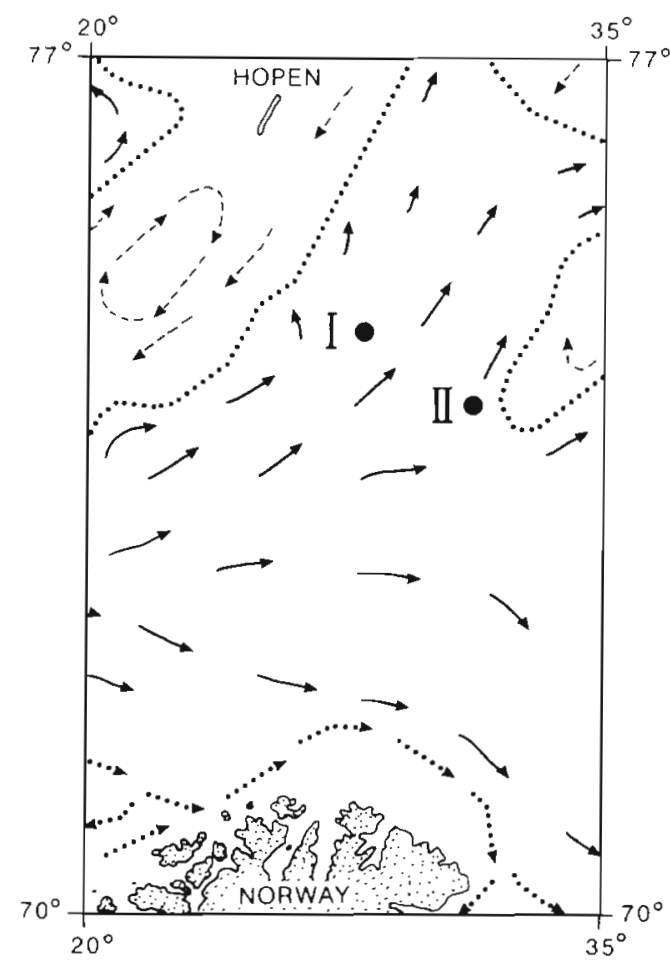

Fig. 1. Stations I and II in the central Barents Sea. Solid arrows: Atlantic water dashed arrows: Arctic water Dotted line: Polar Front between Atlantic and Arctic Water. Dotted arrows: coastal water close to the Norwegian coast

analysed with an elemental analyser (Carlo Erba, model 1106). Duplicate samples for the determination of chlorophyll $a$ and phaeopigments were filtered onto Millipore membrane filters $(0.45 \mu \mathrm{m})$ and analysed on board according to Holm-Hansen et al. (1965) using a Turner Designs fluorometer (model 10-005) calibrated with chlorophyll a (Sigma). Seawater containing large amounts of Phaeocystis pouchetii colonies is difficult to filter due to clogging of the filter by mucilage. Presumably most of this mucilage was not retained by the filters (Lancelot \& Mathot 1985). Care was taken that the negative pressure during filtration did not increase to more than $0.4 \mathrm{~kg} \mathrm{~cm}^{-2}$. Filtration of each sample usually took less than $20 \mathrm{~min}$. Water samples were stored cool and in the dark, and filtration was completed less than $6 \mathrm{~h}$ after sampling.

Samples for HPLC analysis of suspended pigments were collected with 5 or 301 Niskin bottles and filtered onto Whatman GF/F filters. Filtration time of each HPLC samples was less than $1 \mathrm{~h}$. After filtration, samples were stored at $-80^{\circ} \mathrm{C}$ until analysis in the laboratory. Samples were transported on dry ice to San Diego, California. For both analysis, pigments were extracted with $90 \%$ acetone for 24 h at $4{ }^{\circ} \mathrm{C}$.

A reverse-phase step-wise gradient elution system was used for quantitative HPLC analysis of chlorophylls and photosynthetic accessory pigments 
(Vernet \& Lorenzen 1987). Three solvents were employed: $90: 10$ methanol:water (v/v), $94: 6$ methanol: water $(\mathrm{v} / \mathrm{v})$ and $100 \%$ methanol at the rate of $1 \mathrm{ml} \mathrm{min}{ }^{-1}$. All chemicals were HPLC grade. The first solvent reagent contained a buffer (ammonium acetate) and the ion-pairing reagent tetra-butyl ammonium acetate (Mantoura \& Llewellyn 1983). The column was a $4.3 \mathrm{~mm} \times 25 \mathrm{~cm} \mathrm{C}-18$ Econosphere from Alltech with $5 \mu \mathrm{m}$ particles. Pigments were detected by absorbance at $440 \mathrm{~nm}$. Pigment concentration was calculated by manually measuring the corresponding peak area (height $\times$ width at $1 / 2$ height).

Pigments in the water column were identified by cochromatography with known pigments and by determination of their absorption spectra in the eluent (Wright \& Shearer 1984). A second HPLC system was used to qualitatively characterise the pigments in the chromatogram. The column was a C-18 Spherisorb ODS-5, $4.6 \mathrm{~mm} \times 25 \mathrm{~cm}$, with $5 \mu \mathrm{m}$ particles. Two solvents, $A$ and $B$, were pumped through a column with precolumn at $1.0 \mathrm{ml} \mathrm{min}^{-1}$ in a linear gradient starting at $100 \% \mathrm{~A}$ and reaching $100 \% \mathrm{~B}$ after $12 \mathrm{~min}$. Solvent A consisted of $80: 20$ methanol : water (v/v) with $10 \%$ of the water added containing the ion-pairing reagent (Mantoura \& Llewellyn 1984). Solvent B was 60:40 methanol : ethyl acetate $(\mathrm{v} / \mathrm{v})$. Absorption spectra of the eluting pigments were performed in an Hitachi U-2000 spectrophotometer, with a flow-through cell. Phaeopigments were estimated in this system.

Macrozooplankton was sampled by vertical net tows (70 to $0 \mathrm{~m}$ ), sorted under a microscope, and incubated at $0{ }^{\circ} \mathrm{C}$ in the dark in defecation chambers filled with filtered seawater. After $24 \mathrm{~h}$ faecal pellets were collected with a pipette and concentrated for pigment analysis.

Sedimentation was measured below the euphotic zone at 50 and $100 \mathrm{~m}$ depth for periods ranging from 4 to $11 \mathrm{~d}$ (average $7 \mathrm{~d}$ ) using double cylindrical PVC traps with a height of $1.6 \mathrm{~m}$ and a diameter of $0.16 \mathrm{~m}$ (H/D ratio of 10$)$. No poisons were used during the deployments. Therefore, some decomposition and grazing of organic matter inside the traps may have taken place. The contents of each trap were transferred along with about 21 of seawater to a bottle and thoroughly mixed before subsampling. Triplicate subsamples ( 5 to $100 \mathrm{ml}$ ) were taken and filtered for analysis of POC, PON, chlorophyll a, and phaeopigments. The material from the traps was microscopically examined on board.

The photosynthesis-irradiance ( $P$ vs I) response of phytoplankton in the sediment traps at $100 \mathrm{~m}$ depth was determined in an incubator which was kept at the relevant in situ temperature. The light source was a $400 \mathrm{~W}$ halogen-metal lamp (Osram HQI-T $400 \mathrm{~W} / \mathrm{DH}$ ). Ten different scalar irradiances ranging from 0 to about
$1700 \mu \mathrm{mol} \mathrm{m} \mathrm{m}^{-2} \mathrm{~s}^{-1}$ were obtained using neutral filters made of plexiglass. An aliquot of $150 \mathrm{ml}$ of the trap suspension was thoroughly mixed with $740 \mathrm{kBq}$ $(20 \mu \mathrm{Ci})$ of sodium bicarbonate in automatic pipette system. Ten $\mathrm{ml}$ of this mixture was added to 11 separate scintillation vials. Ten vials were incubated for $1 \mathrm{~h}$ in the incubator, and 1 vial was wrapped in aluminium foil and placed in the cooling water as control.

After incubation, the samples were immediately filtered in dim light through Millipore membrane filters $(0.45 \mu \mathrm{m})$ which were rinsed with filtered seawater. The filters were exposed to fumes of concentrated $\mathrm{HCl}$ for 2 to $3 \mathrm{~h}$ in a sealed container, after which $7 \mathrm{ml}$ of Optifluor scintillation cocktail was added. Radioactivity was measured on board in a Packard Tri-Carb 4430 scintillation counter using the channel ratio method for estimating quenching. Photosynthetic rate was determined after subtraction of the dark fixation. Parameters of the P-I curves were determined according to the model of Platt \& Gallegos (1980), using an iteration programme.

\section{RESULTS}

\section{Hydrographic conditions}

In May/June little stratification had developed at Station I (Fig. 2A). Nitrate in the euphotic zone was < $1 \mu \mathrm{M}$ at the beginning and was non-detectable at the end of the investigation. This indicates that the summer situation, which is characterised by nutrient limitation, had begun (Fig. 2B). Phosphate also decreased, but was presumably non-limiting (Fig. 2D). Maximum ammonia concentrations up to $2 \mu \mathrm{M}$ were observed below the euphotic zone (Fig. 2C) and indicate either higher uptake of regenerated nitrogen in the photic zone or higher grazing and regeneration rates of nitrogen below the photic zone. Silicate was, however, much less depleted than nitrate at the beginning of the sampling period (Fig. 2E), suggesting that diatoms were not predominant during the vernal bloom at Station I. Active uptake of silicate, most probably by diatoms, was observed as the silicate concentration decreased by half within $1 \mathrm{wk}$

Station II was influenced by fresh water from melting sea ice. This is indicated by the increasing stratification with time (Fig. 2F). Nitrate in the euphotic zone was low (Fig. 2G) as were phosphate and silicate (Fig. 2I, J). The ammonia distribution was similar to that of that Station I (Fig. 2H). The observed silicate depletion indicates that diatoms contributed to an early vernal bloom.

Advection of nutrient-rich (but low-ammonium) water was observed at both stations. This was observed from 25 to $75 \mathrm{~m}$ depth at Station II in late May, and less significantly from 50 to $100 \mathrm{~m}$ at Station I in early June. 

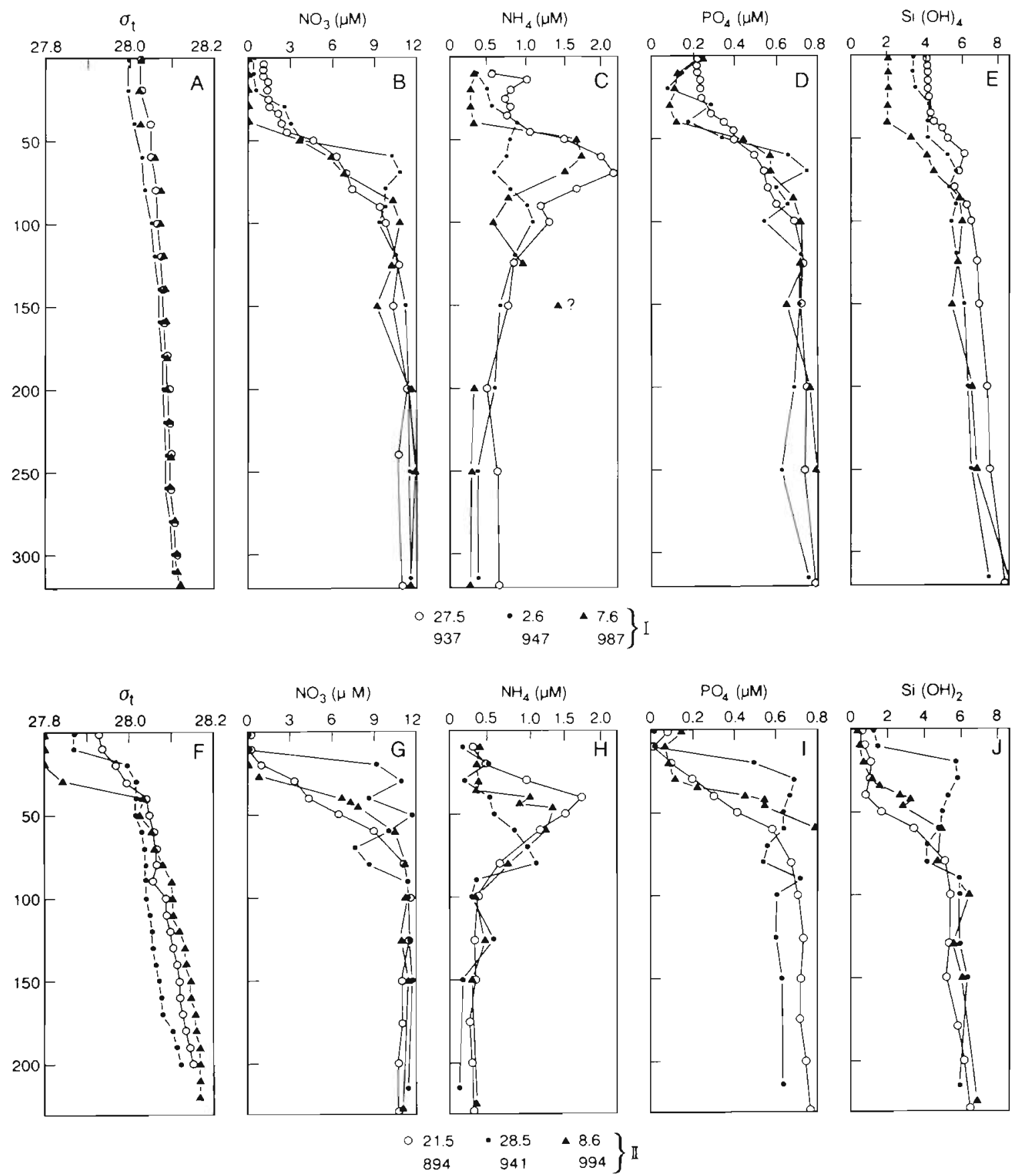

Fig. 2. Vertical distribution of density $\left(\sigma_{\mathrm{t}}\right)$, nitrate, ammonia, phosphate and silicate during May/June at Stations I and II in the Barents Sea

\section{Suspended biomass}

Phaeocystis pouchetii was a prominent species at both stations and was predominant at Station I. At the time of the first deployment, an average of $13500 \mathrm{P}$. pouchetii colonies $\mathrm{l}^{-1}$ were found in the upper $50 \mathrm{~m}$ (average of 628 cells per colony; C. Hewes pers. comm.). Diatoms were also present at both stations, although in low concentrations.

High biomass and pigments from the surface to $70 \mathrm{~m}$ at Station I indicate that the vernal bloom was still in progress (Fig. 3A, C, D). The PON/POC ratio clearly decreased over time, which might suggest nitrogen limitation (Fig. 3B). Observed depletion of nitrate in 


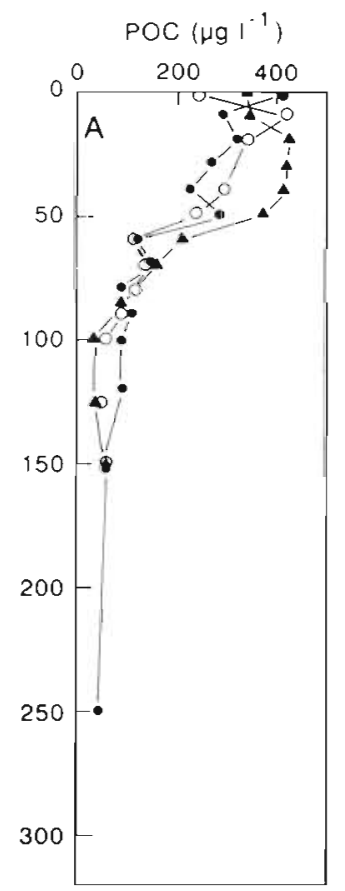

PON/POC (a/a)
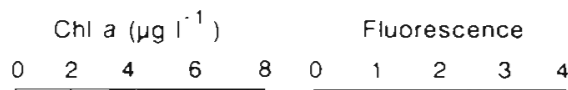

Chl a /Phaeo $(w / w)$
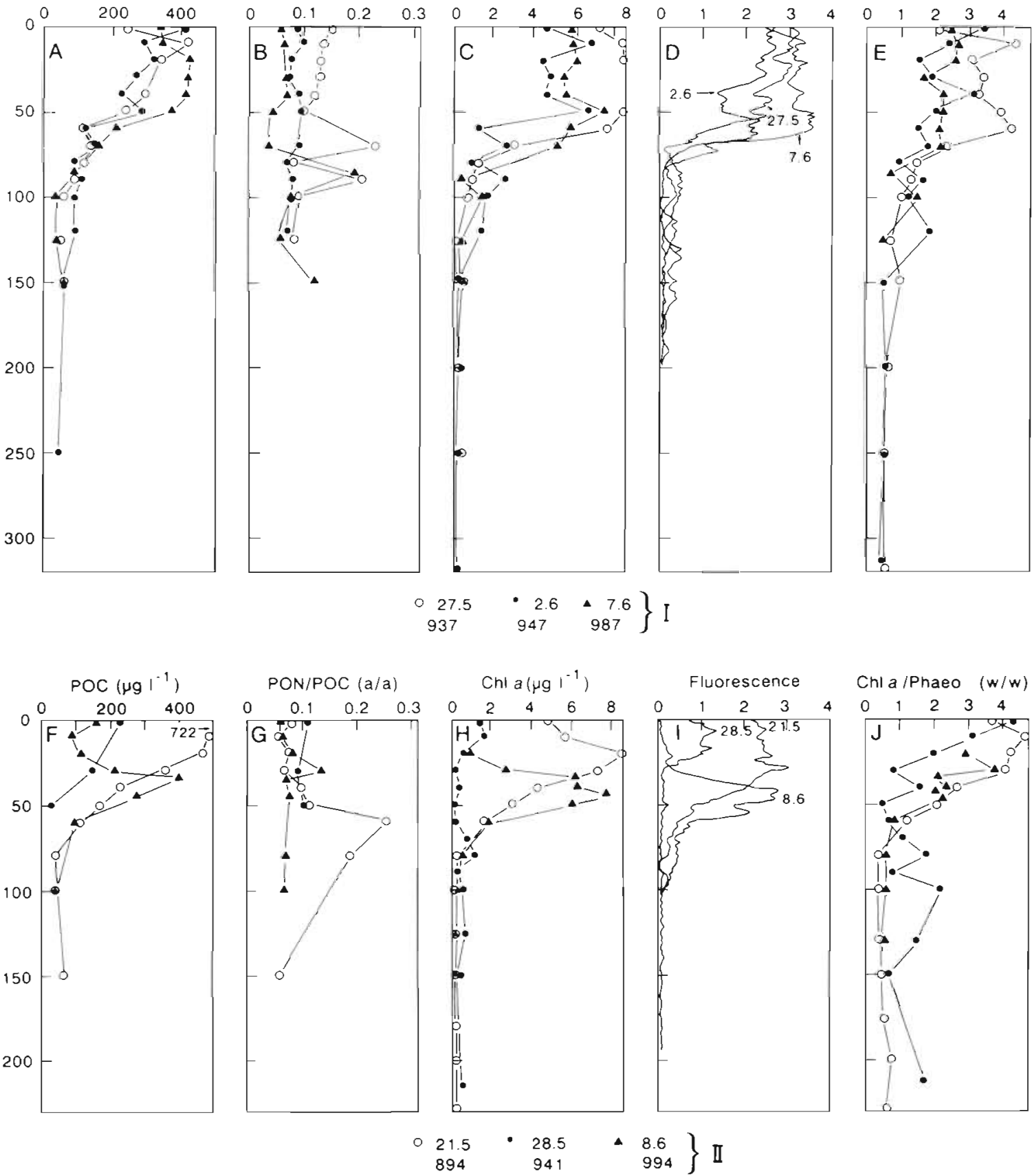

Chl a /Phaeo $(w / w)$

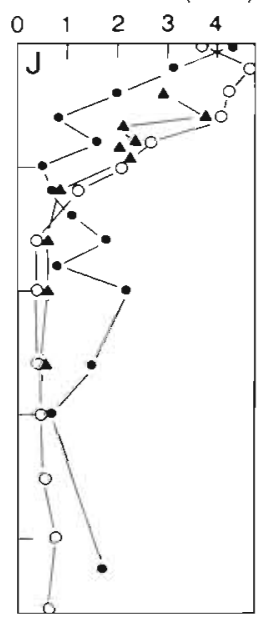

Fig. 3. Vertical distribution of particulate organic carbon (POC), chlorophyll a (chl $a$ ), in vivo fluorescence, and the relationship between particulate organic nitrogen and POC (PON/POC) and phaeopigments (chl $a /$ phaeo) during May/June at Stations I and II in the Barents Sea

surface waters at Station I (Fig. 2B) supports this hypothesis. Colonial stages of Phaeocystis pouchetii are however characterised by large amounts of mucilage rich in carbon and poor in nitrogen (Lancelot et al. 1987). The PON/POC ratio may therefore primarily reflect the dynamics of mucus production by the $P$. pouchetii colonies (nitrate was still measurable).

The time development of suspended biomass and pigments at Station II reflects the progress of a plankton community from the end of the vernal bloom to a summer situation in which nutrient limitation was significant in surface waters. This seasonal transition was characterised by a change from uniformly high biomass in surface waters during the vernal bloom to low biomass in surface waters with a strong subsurface biomass maximum in the nutricline (Fig. $3 \mathrm{~F}$ to I). 
The spring-summer transition observed at Station II was not observed at Station I. Overall, biomass at Station I was relatively high and constant, although nutrients did decline. A small but significant decrease over time in chl a/phaeo ratios at both stations suggests an increasing importance of grazing (Table 1). The chl a/phaeo ratio and total biomass decreased more at Station II indicating that grazing may play a role in the decrease of surface biomass in the spring-summer transition.

The pigment composition, in particular the presence of chlorophyll $c_{3}$, reflects the predominance of prymnesiophytes (Table 2). Similar to other prymnesiophytes, Phaeocystis pouchetii is characterised by chlorophyll $c_{3}$ in addition to chlorophyll $c_{1}$ (Jeffrey \& Wright 1987). Other accessory pigments observed include diadinoxanthins and low $\beta$-carotene. The main carotenoid found at the ice-edge in the Barents Sea was fucoxanthin. This indicates that the Arctic strain is similar to the $P$. pouchetii found in the North Sea (W. W. Gieskes pers. comm.), but different from Antarctic strains where $19^{\prime}$-hexanoylfucoxanthin replaces fucoxanthin as the major light-harvesting pigment (Wright \& Jeffrey 1987)

Profiles of chlorophyll $c\left(c_{3}+c_{1}\right)$, fucoxanthin and diadinoxanthin, the more abundant accessory pig- ments found at the ice-edge, follow the distribution of POC and chlorophyll $a$ at both stations (Fig. 4).

\section{Sedimentation of organic matter}

Vertical loss of organic matter from the euphotic zone was far higher at Station I than at Station II (Tables 2 and 3). The POC, PON and pigment sedimentation rates at Station I are the highest rates recorded from the Barents Sea so far (Wassmann 1989). Significant sedimentation of phytoplankton at Station I is also suggested by the variable fluorescence below $70 \mathrm{~m}$ depth (Fig. 3D). Sedimentation rates of organic matter and pigments at Station II (Table 3) were comparable to those recorded previously during early summer periods. Sedimented matter was dominated by colonial stages of Phaeocystis pouchetii. This was most evident for $50 \mathrm{~m}$ depth at Station 1. Also present in the traps were variable amounts of faecal pellets and phytodetritus. At Station I a light green, slimy and 4 to $6 \mathrm{~cm}$ thick mass of $P$. pouchetii accumulated in the traps at $50 \mathrm{~m}$ depth. Loss of DOC from $P$. pouchetii mucilage during filtration (Lancelot \& Mathot 1985) inevitably gave rise to underestimation of sedimentation rates.

Sedimentation rates decreased significantly between

Table 1. Integrated suspended biomass in the upper $50 \mathrm{~m}$ of the water column in the Barents Sea during May/June $1987\left(\mathrm{mg} \mathrm{m}^{-2}\right.$ ). Values are averages of the deployment and recovery stations. Also shown are various ratios characterising the quality of organic matter. Chlorophyll (Chl) a and phaeopigment (Phaeo) data are from fluorescence analysis. (a/a): atomic ratio; (w/w): weight ratio

\begin{tabular}{|c|c|c|c|c|c|c|c|c|}
\hline Station & Time interval & POC & PON & Chl a & Phaeo & $\begin{array}{c}\text { PON/POC } \\
(a / a)\end{array}$ & $\begin{array}{c}\text { Chl a/phaeo } \\
(w / w)\end{array}$ & $\begin{array}{c}\text { Chi a/POC } \\
(w / w)\end{array}$ \\
\hline \multicolumn{9}{|l|}{ Station I } \\
\hline $937-947$ & $27 \mathrm{May}-2$ Jun & 16560 & 2004 & 366 & 127 & 0.121 & 2.88 & 0.022 \\
\hline $947-987$ & $2-7$ Jun & 19665 & 1496 & 283 & 126 & 0.076 & 2.25 & 0.014 \\
\hline \multicolumn{9}{|l|}{ Station II } \\
\hline $894-941$ & 21-28 May & 13790 & 1340 & 168 & 46 & 0.097 & 3.65 & 0.012 \\
\hline $941-994$ & 28 May-8 Jun & 8672 & 1009 & 94 & 42 & 0.116 & 2.24 & 0.011 \\
\hline
\end{tabular}

Table 2. Daily loss rates of suspended biomass (\%) from the upper $50 \mathrm{~m}$ at 2 locations during May/June 1987 in the Barents Sea due to sedimentation

\begin{tabular}{|c|c|c|c|c|c|c|}
\hline Station & POC & PON & $\mathrm{Chl} \mathrm{a}^{\mathrm{a}}$ & Chl $\subseteq$ & Fucoxanthin & Diadinoxanthin \\
\hline \multicolumn{7}{|l|}{ Station I } \\
\hline $937-947$ & 3.47 & 3.31 & 2.44 & 2.22 & 1.75 & 1.87 \\
\hline $947-989$ & 4.25 & 5.62 & 2.87 & 1.31 & 5.19 & 4.86 \\
\hline \multicolumn{7}{|l|}{ Station II } \\
\hline $894-941$ & 0.67 & 0.63 & 1.98 & - & - & - \\
\hline $941-994$ & 0.57 & 0.59 & 0.64 & 0.37 & 0.20 & 0.58 \\
\hline
\end{tabular}


Chiorophyll a

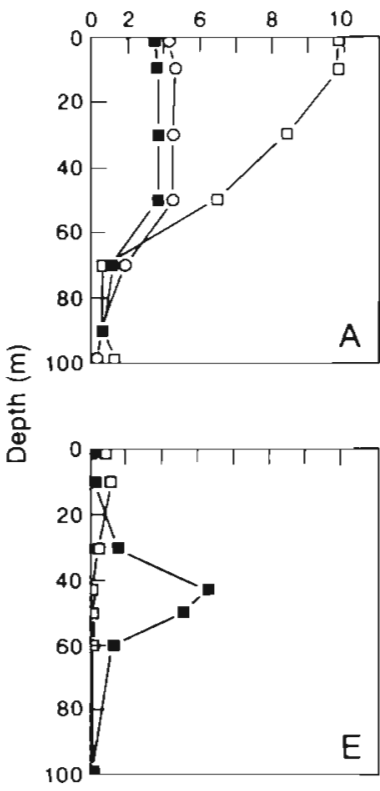

Chlorophyll $c$

Fucoxanthin $(\mu \mathrm{g} / \mathrm{l})$

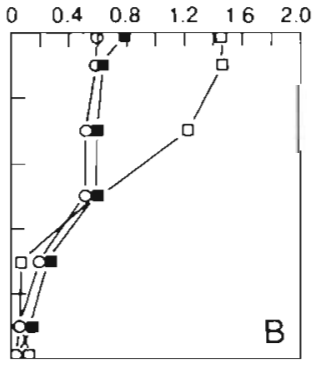

Station I ( $\square$ 937;

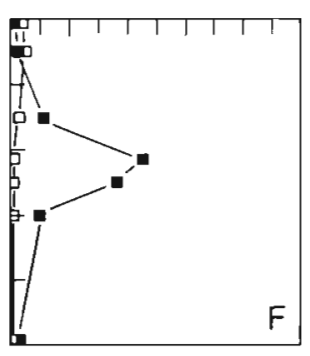

Station II ( $\square$ 941; - 994)
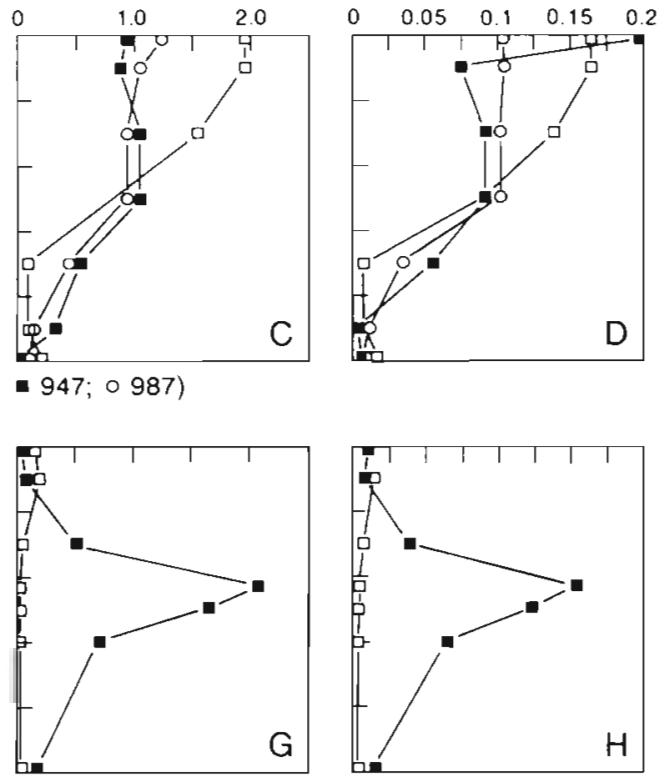

Fig. 4. Vertical distribution of chlorophyll a, chlorophyll $c$, diadinoxanthin and fucoxanthin during May/June at Stations I and II in the Barents Sea as analysed by HPLC

Table 3. Average sedimentation and standard deviation (\%) of particulate organic carbon and nitrogen (POC, PON), chlorophyll a and phaeopigments derived from double traps at 2 stations in the Barents Sea during May/June 1987 ( $\mathrm{mg} \mathrm{m}^{-2} \mathrm{~d}^{-1}$ ). Also shown are ratios characterising the quality of settled organic matter: $\mathrm{PON} / \mathrm{POC}, \mathrm{chl} a / \mathrm{phaeo}$ and $\mathrm{chl} a / \mathrm{POC} . \mathrm{P}_{\max }\left(\mathrm{mg} \mathrm{C}[\mathrm{mg} \mathrm{chl} \mathrm{a}]^{-1} \mathrm{~h}^{-1}\right)$ of the settled matter at $100 \mathrm{~m}$ is indicated

\begin{tabular}{|c|c|c|c|c|c|c|c|c|c|}
\hline Station & $\begin{array}{l}\text { Depth } \\
\text { (m) }\end{array}$ & POC & PON & Chl a & Phaeo & $\begin{array}{c}\mathrm{PON} / \mathrm{POC} \\
(\mathrm{a} / \mathrm{a})\end{array}$ & $\begin{array}{l}\text { Chl af } \\
\text { phaeo } \\
(w / w)\end{array}$ & $\begin{array}{l}\text { Chl af } \\
\text { POC } \\
(w / w)\end{array}$ & $P_{\max }$ \\
\hline \multicolumn{10}{|l|}{ Station I } \\
\hline $937-947$ & $\begin{array}{r}50 \\
100\end{array}$ & $\begin{array}{l}575 \pm 15 \\
223 \pm 22\end{array}$ & $\begin{array}{l}66.3 \pm 12 \\
23.4 \pm 14\end{array}$ & $\begin{array}{l}6.91 \pm 16 \\
1.65 \pm 10\end{array}$ & $\begin{array}{l}5.11 \pm 28 \\
3.20 \pm 14\end{array}$ & $\begin{array}{l}0.099 \\
0.091\end{array}$ & $\begin{array}{l}1.35 \\
0.52\end{array}$ & $\begin{array}{l}0.012 \\
0.007\end{array}$ & 0.4 \\
\hline $947-987$ & $\begin{array}{r}50 \\
100\end{array}$ & $\begin{array}{l}835 \pm 13 \\
198 \pm 12\end{array}$ & $\begin{array}{l}84.1 \pm 10 \\
23.2 \pm 11\end{array}$ & $\begin{array}{l}6.80 \pm 4 \\
1.63 \pm 11\end{array}$ & $\begin{array}{l}4.94 \pm 10 \\
2.57 \pm 7\end{array}$ & $\begin{array}{l}0.087 \\
0.104\end{array}$ & $\begin{array}{l}1.40 \\
0.63\end{array}$ & $\begin{array}{l}0.008 \\
0.008\end{array}$ & 0.5 \\
\hline $\begin{array}{l}\text { Station II } \\
894-941\end{array}$ & $\begin{array}{r}50 \\
100\end{array}$ & $\begin{array}{l}93 \pm 19 \\
97 \pm 9\end{array}$ & $\begin{array}{r}8.4 \pm 27 \\
10.2 \pm 17\end{array}$ & $\begin{array}{l}0.80 \pm 11 \\
0.57 \pm 9\end{array}$ & $\begin{array}{l}3.43 \pm 10 \\
3.54 \pm 4\end{array}$ & $\begin{array}{l}0.077 \\
0.105\end{array}$ & $\begin{array}{l}0.23 \\
0.16\end{array}$ & $\begin{array}{l}0.009 \\
0.006\end{array}$ & 0.6 \\
\hline $941-994$ & $\begin{array}{r}50 \\
100\end{array}$ & $\begin{array}{l}49 \pm 13 \\
64 \pm 6\end{array}$ & $\begin{array}{l}6.0 \pm 20 \\
7.3 \pm 6\end{array}$ & $\begin{array}{l}0.20 \pm 22 \\
0.51 \pm 3\end{array}$ & $\begin{array}{l}0.67 \pm 3 \\
1.76 \pm 3\end{array}$ & $\begin{array}{l}0.122 \\
0.114\end{array}$ & $\begin{array}{l}0.29 \\
0.29\end{array}$ & $\begin{array}{l}0.004 \\
0.008\end{array}$ & 0.2 \\
\hline
\end{tabular}

50 and $100 \mathrm{~m}$ at Station I suggesting dissolution, breakdown and grazing of the settling matter, in contrast to Station II, where vertical fluxes were more uniform. High chl a/POC ratios indicate a high abundance of phytoplankton in the traps at both stations (Tables 3 and 4). The sedimented matter at Station I was dominated by chlorophyll $a$ at $50 \mathrm{~m}$ and by phaeopigments at $100 \mathrm{~m}$ depth while at Station II phaeopigments were always predominant.
The daily loss rates for suspended organic matter clearly indicate the differences in plankton dynamics between Station I and II (Table 2). From 3 to $6 \%$ suspended POC and PON in the upper $50 \mathrm{~m}$ was sedimented daily at Station I. At Station II, however, on average $0.61 \%$ of suspended POC and PON left the euphotic zone. Daily loss rates for pigments at Station I were more variable than loss rates for POC and PON, but of the same order of magnitude and always $<5 \%$ 
Table 4. Comparison of biochemical composition of organic matter from the water column (WC; integrated 0 to $50 \mathrm{~m}$ ), sedimented matter (SM) and combined faecal pellets (FP) of macrozooplankton (Calanus finmarchicus, C. hyperboreus, Metridia longa and Thyssanoessa inermis) collected by vertical net tows from 70 to $0 \mathrm{~m}$. Pigment ratios are based on HPLC analysis. POC/PON: a/a; pigment ratios: $w / w$

\begin{tabular}{|lcccccccc}
\hline Ratios & \multicolumn{3}{c}{ Station I } & \multicolumn{3}{c}{ Station II } \\
& WC & \multicolumn{2}{c}{ SM } & WC & \multicolumn{2}{c}{ SM } \\
& & $50 \mathrm{~m}$ & $100 \mathrm{~m}$ & & $50 \mathrm{~m}$ & $100 \mathrm{~m}$ \\
\hline PON/POC & 0.096 & 0.093 & 0.097 & 0.104 & 0.099 & 0.109 & - \\
Chl a/POC & 0.020 & 0.002 & 0.006 & 0.008 & 0.006 & 0.002 & - \\
Chl a/PON & 0.209 & 0.016 & 0.05 & 0.079 & 0.060 & 0.020 & - \\
Chl a/chl C & 9.52 & 1.07 & 2.17 & 14.3 & 8.62 & 4.28 & 7.69 \\
Chl a/fucoxanthin & 5.26 & 1.33 & 2.04 & 6.45 & 5.55 & 3.12 & 2.94 \\
Chl a/diadinoxanthin & 42.6 & 13.8 & 16.4 & 66.7 & 27.4 & 15.6 & 30.3 \\
Chl a/phaeophytin & - & 33.4 & 11.8 & - & 3.84 & 3.70 & 1.72 \\
Chl a/phaeophorbide & - & 1.26 & 0.77 & - & 0.67 & 0.44 & 0.66 \\
\hline
\end{tabular}

(Table 2). Again Station II had, on average, about 5 times lower loss rates than Station I.

The PON/POC ratio was relatively invariant between suspended and sedimenting material for all samples (Table 4 ). The typical value (about 0.1 ) is ca $30 \%$ less than the Redfield ratio for exponentially growing phytoplankton (0.16), as might be expected for carbon-rich colonies of Phaeocystis pouchetii (Verity et al. 1988). The chl a/POC ratio was highest for suspended matter at Station $I$ and is in the range expected for phytoplankton during spring blooms. Sediment trap material at Station I had much lower chl a/POC ratios. At Station II, the chl a/POC ratio in the water column was low, an observation typical of oljgotrophic systems where detrital concentrations are relatively high. The composition of sedimenting material at Station II was similar to that observed at Station I.

The main carotenoids present in seston were also found in copepod faecal pellets and sedimented matter. The ratio of $\mathrm{chl}$ a/carotenoids was highest in seston and lowest in sediment traps, as expected if chlorophyll a was the pigment that degraded fastest. The higher values of chl a/carotenoids at Station II suggest differences in the processes that transform phytoplankton pigments.

Several phaeophorbide- and phaeophytin-like molecules were observed in abundance in sedimenting material and faecal pellets as observed in temperate waters (Vernet \& Lorenzen 1987). Phaeophorbide was always more abundant than phaeophytin and was relatively more important at Station II than in Station I. Chlorophyll a clearly dominated sedimentation at $50 \mathrm{~m}$ at Station I.

$P$ vs I curves from the sedimented matter at $100 \mathrm{~m}$ depth indicate that much of the sedimented matter consisted of photosynthetically viable phytoplankton. This is reflected in the $P_{\max }$ values presented in Table 3 . $P_{\max }$ values from the water column at Station I and II
(0 to $90 \mathrm{~m}, \mathrm{n}=15$ ) ranged from 0.4 to $1.7 \mathrm{mg} \mathrm{C}$ ( $\mathrm{mg}$ chl $a)^{-1} h^{-1}$ (average $=1.1 ; F$. Rey unpubl.). Values for sediment trap material ranged from 0.2 to 0.6 .

\section{DISCUSSION}

Massive sedimentation of organic matter following phytoplankton blooms has been documented for both coastal and oceanic environments, including polar areas (Schnack et al. 1984, Bodungen et al. 1986). Ungrazed diatoms and diatom-derived detritus often dominate vertical flux at the end of the vernal bloom (Smetacek 1985). Slimy colonies of a prymensiophyte algae like Phaeocystis pouchetii have, however, not been reported to contribute significantly to the vertical flux of phytoplankton-derived detritus. $P$. pouchetii can develop blooms in water mixed as deep as 60 to $100 \mathrm{~m}$, where diatoms generally do not develop blooms (Sakshaug \& Holm-Hansen 1984) and appears to be more efficient at marginally low light than many other species (Eilertsen et al. 1981, Palmisano et al. 1986), The massive bloom observed in the weakly stratified Atlantic surface water at Station I (Figs. $2 \mathrm{~A}$ and 3D), where more than half of the biomass is below the euphotic zone, and the deposition of viable, shadeadapted cells as deep as $100 \mathrm{~m}$ (Table 3), shows the ability of these algae to live in low-light environments.

Compared to the marginal ice zone close to the Polar front, where the phytoplankton spring bloom takes place in late April/early May, the bloom in the Atlantic water develops more slowly and peaks about 1 mo later in May/June (Skjoldal \& Rey 1989, Wassmann \& Slagstad unpubl.). This variation in the timing of the bloom is caused by differences in water column stabilisation due mainly to warming by solar radiation in Atlantic water, but due to rapidly melting sea-ice in the marginal ice zone. These differences in the bloom dynamics 
are reflected by Station I dominated by Atlantic water and Station II in the marginal ice zone close to the Polar Front. During the investigated period at Station I a spring bloom at its maximum was observed as reflected by the pigment concentrations and fluorescence (Fig. 3C, D). A senescent stage of the spring bloom with rapidly declining pigment concentrations was observed at Station II (Fig. 3H, I). The observed variability at Station II reflects not only the general dynamics of a senescent bloom in a stratified body of water, but also the advection of increasingly 'mature' bodies of water from the Polar Front area as suggested by variation in density and nutrient concentrations (Fig. 2F to J).

\section{Phaeocystis pouchetii blooms and vertical flux of organic matter}

The sedimentation rates of POC, PON and especially pigments at Station I (Table 3) are among the highest rates recorded from oceanic environments such as the Norwegian Sea (Bathmann et al. 1987), the Norwegian coastal current (Peinert et al. 1987), and the North Pacific (Martin et al. 1987), and are even higher than rates from the Norwegian coastal zone (Wassmann 1984). Compared to oceanic environments like the neighbouring Norwegian Sea the Barents Sea functions in terms of magnitude and time variation of sedimentation rates more like a coastal area. High values of chl a/phaeopigments, chl a/POC and chl aspecific rates of photosynthesis for sedimenting material during this study suggest a large fraction of the flux is comprised of viable phytoplankton. Microscopic analysis confirmed that Phaeocystis poucheti was the dominant phytoplankton species.

The presence of carbon-rich mucus of Phaeocystis pouchetii colonies gives rise to $\mathrm{PON} / \mathrm{POC}$ ratios well below the Redfield ratio of 0.16 (Verity et al. 1988), as seen in the present results (Table 4 ). However, chl a/ POC ratios are high (Tables 1 and 4 ). The suspended and sedimenting matter of $P$. pouchetii blooms is thus characterised by low nitrogen and high carbon and chlorophyll a concentrations. To fully utilise the rich carbon source of $P$. pouchetii derived matter, heterotrophic organisms colonising detritus will require an alternative nitrogen source. Profiles of POC, chlorophyll $a$, in situ fluorescence (Fig. 3) and in situ beam attenuation coefficients (G. Mitchell unpubl.) indicate that less than $10 \%$ of surface values of these particulate variables is present at $200 \mathrm{~m}$ depth. High sedimentation rates in shallow water and the low concentration of suspended particulates at depth indicate significant remineralisation at depths less than $100 \mathrm{~m}$, as reflected by ammonia accumulation in the 50 to $100 \mathrm{~m}$ depth interval (Fig. 2C, H) and decreased sedimentation rates at $100 \mathrm{~m}$ (Table 3). Remineralisation of $P$, poucheti. derived detritus by bacteria requires assimilation of dissolved nitrogen compounds. Alternatively, grazers may consume the sedimenting material, and repackage as faecal pellets what they did not assimilate. Dense but relatively rare faecal pellets would not contribute significantly to any of the particulate variables we measured at $200 \mathrm{~m}$

The sedimentation rate at $50 \mathrm{~m}$ at Station I might be overestimated if other processes besides net sinking are in play. Traps positioned in the middle of a bloom, particularly in a mixed layer, could receive particles from below the trap via processes similar to resuspension of particles from sediments. However, we think this was not a dominant process in this case as the $50 \mathrm{~m}$ trap was located in water which was stratified, albeit weakly (average $\Delta \sigma_{\mathrm{t}}[0-50 \mathrm{~m}]=0.17$ ).

Compared to suspended matter, chl a/POC ratios in sedimented material were low (Table 4), particularly in traps at $100 \mathrm{~m}$ depth. Only in the $50 \mathrm{~m}$ trap at Station I was chlorophyll a the predominant pigment. Our interpretation is that viable Phaeocystis pouchetii cells are the main source of sedimentation at this depth. The pigment ratios in faecal pellets from isolated macrozooplankton individuals indicate that grazing may represent an important pigment loss from the upper layers of the Barents Sea during spring. The phytoplankton pigments found in the traps are, therefore, interpreted as a combination of pigment sinking in association with intact phytoplankton cells and undegraded pigments present in macrozooplankton faecal pellets. Chl aspecific $P_{\max }$ values were ca $50 \%$ of the typical values for phytoplankton in the Barents Sea (Rey et al. 1987).

Undegraded carotenoids are found in copepod guts (Keppel 1988) and faecal pellets (Nelson 1989, Roy et al. 1989). The same is true for accessory chlorophylls (Vernet \& Lorenzen 1987). Degraded forms of carotenoids are also produced by macrozooplankton (Repeta \& Gagosian 1982), but mainly by larger forms such as euphausiids and salps (Nelson 1989). These degraded forms were not abundant in this study, probably due to high sedimentation rates of viable phytoplankton and the copepod dominance of macrozooplankton in the Barents Sea (Zenkievitch 1963, Tande \& Bămstedt 1985, Skjoldal et al. 1987).

The flux of pigments as a percentage of integrated water column values are similar to those for POC and PON (Table 2) suggesting that pigments can be used to estimate losses of phytoplankton carbon in the Barents Sea. Several studies have pointed out that low concentrations of chlorophyll a and phaeopigments in copepods is due to transformation during gut passage, which renders them undetectable by standard methods of pigment analysis (Wang \& Conover 1986, Lopez et 
al. 1988). The similar percent loss of pigments, POC and PON indicates a dominance of ungrazed phytoplankton sinking and/or a conservation of chlorophyll equivalents (chlorophyll a + phaeopigments) during gut passage.

\section{Plankton dynamics during Phaeocystis pouchetii blooms}

At both stations zooplankton had little apparent influence on recycling of material from the Phaeocystis pouchetii bloom in the upper $50 \mathrm{~m}$, coinciding with massive flux of biogenic particulates from the aphotic zone (Table 3). The resulting nutrient depletion of the euphotic zone following $P$. pouchetii blooms is thus substantial, especially in the stratified waters of the marginal ice zone and the Polar Front represented by Station II. Even at Station I, where zooplankton grazing was observed (H. R. Skjoldal pers. comm.), grazers were not able to cope with the rapid phytoplankton production in May/June (ca $1.5 \mathrm{~g} \mathrm{C} \mathrm{m}^{-2} \mathrm{~d}^{-1}$; F. Rey unpubl.). Sedimentation of POC comprised between 36 and $58 \%$ of primary production. At Station $\mathrm{II}, \mathrm{POC}$ sedimentation comprised only 3 to $10 \%$ of primary production.

The high vertical flux rates during Phaeocystis pouchetii blooms have considerable implications for the plankton ecology of the Barents Sea. Large amounts of nitrogen and phosphorus compounds are removed from the euphotic zone by $P$. pouchetii colonies, resulting in a rapidly developing nutrient depletion during early summer. This rapid and extensive removal of food and nutrients from the euphotic zone gives rise to a deterioration of living conditions of zooplankton in surface waters of the Barents Sea after the spring bloom.

The lag time between phytoplankton and zooplankton development can be substantial in the Barents Sea (Skjoldal et al. 1987). This has obvious implications for zooplankton production and pelagic-benthic coupling (Wassmann 1989). The evidence presented here and earlier (Bobrov 1985, Eilertsen et al. 1989, Skjoldal \& Rey 1989) implies that the zooplankton community in the Barents Sea, in contrast to other oceanic environments like the North Pacific (Frost et al. 1983) and the Norwegian Sea (Peinert et al. 1989), is usually not able to control the phytoplankton spring bloom.

\section{Phaeocystis pouchetii and marine snow formation}

Exponentially growing Phaeocystis pouchetii colonies are free from surface bacteria due to a moderate antibacterial property of their mucilage (acrylic acid)
(Sieburth 1979). The extracellular polymeric material of aged $P$, pouchetii colonies, however, gives rise to adhesive webs and sticky capsular secretions which are easily colonised by bacteria ( $F$. Thingstad unpubl.) and pennate diatoms (Estep et al. 1990) during senescence. The stickiness of $P$. pouchetii colonies is important for the biologically enhanced physical aggregation during vertical transport (Jackson 1990) which in turn gives rise to macroaggregates (marine snow) (Alldredge \& Silver 1988). These aggregates sink and also remove other particles (e.g. algae, faecal pellets, detritus) from the upper layers as indicated by the results of the present study and visual observations from the bottom of the North Sea (U. Riebesell pers. comm.). Marine snow formation enhances the depletion of particulate and dissolved matter from surface water. The export of dissolved organic carbon by $P$. pouchetii to the aphotic zone may also be an important mechanism for removal of $\mathrm{CO}_{2}$ from the atmosphere (Toggweiler 1989). We hypothesise that $P$. pouchetii is a significant contributor to the formation of marine snow in polar and boreal oceans. This is an important, but inadequately studied, aspect of its ecology.

Autolysis, production of exudates, bacterial colonisation of sinking colonies and amorphous material during Phaeocystis pouchetii blooms (Bätje \& Michaelis 1986, Davidson \& Marchant 1987, Vaqué et al. 1989) and ingestion of bacteria-rich aggregates by copepods (Estep et al. 1990) suggest that particulate and dissolved organic matter derived from $P$. pouchetii blooms is effectively recycled below the euphotic zone. This is clearly reflected by the vertical decrease in sedimentation at Station I and the accumulation of ammonium in the 50 to $100 \mathrm{~m}$ depth interval. Colonies of $P$. pouchetii also contributed significantly to a phytoplankton summer bloom in the Weddel Sea and a north Norwegian fjord, but their contribution to vertical flux at respectively 80 and $20 \mathrm{~m}$ depth and below was small (Bodungen et al. 1988, Lutter et al. 1989). It is, thus, unlikely that major amounts of $P$. pouchetii biomass reach the benthos of the central Barents Sea. The implied degradation of large amounts of the $P$. pouchetii derived material in the upper part of the aphotic zone means that, while sedimentation played a significant role in the removal of $P$. pouchetii from the euphotic zone, relatively little of this material is being delivered to greater depths. Degradation greatly diminishes the likely importance of $P$. pouchetii blooms in processes such as carbon flux to the deep ocean and sequestering of $\mathrm{CO}_{2}$. Observations of $\mathrm{CO}_{2}$ concentrations in the water column are not available from our investigation. However, storage of $\mathrm{CO}_{2}$ at mid-water depths of the Barents Sea is likely during spring and summer. This $\mathrm{CO}_{2}$ will most probably be released to the atmosphere during winter mixing 
We suggest the following sequence of events during $P$. pouchetii blooms in the Barents Sea: (1) Flagellated cells develop into colonies. Antibacterial substances keep surface mucilage free from bacteria. (2) Colonies grow. Nutrient depletion induces increased extracellular mucilage production. Stickiness of colonies increases. Bacteria colonise the surface mucilage. (3) Aggregate formation of colonies and detrital material starts. Marine snow sinks out of the euphotic zone. Autolysis, leakage, rapid microbial degradation and zooplankton grazing take place. (4) Marine snow disintegrates in upper part of the aphotic zone.

Acknowledgements. H. C. Eilertsen, K. Estep, E. Sakshaug, F. Thingstad and $K$. Tande provided comments on the manuscript. P.W. was supported by the Norwegian Research Council for Science and the Humanities (NAVF). M.V. and B.G.M. were supported by National Science Foundation, Division of Polar Programs grant DPP-8520848 to O. Holm-Hansen. We thank U. Båmstedt and H. R. Skjoldal for zooplankton samples, M. Hagebo for nutrient analysis, Geir Johnsen for pigment analyses, C. Hewes for use of data and the crew of RV ' $\mathrm{G}$. O Sars' for a successful cruise. This publication is a contribution from the Norwegian Research Programme for Arctic Ecology (PRO MARE). We thank our colleagues in PRO MARE for the splendid collaboration.

\section{LITERATURE CITED}

Alldredge, A. L., Silver, M. W. (1988). Characteristics, dynamics and significance of marine snow. Prog Oceanogr. 20: 41-82

Bätje, M., Michaelis, H. (1986). Phaeocystis pouchetii blooms in East Frisian coastal waters (German Bight, North Sea). Mar. Biol. 93: 21-27

Barnard, W. R., Andrea, M. O., Iverson, R. L. (1984). Dimethylsulfid and Phaeocystis pouchetii in the southeastern Bering Sea. Cont. Shelf Res. 3: 103-113

Bathmann, U., Noji. T T., Voss, M., Peinert, R. (1987) Copepod fecal pellets: abundance, sedimentation and content at a permanent station in the Norwegian Sea in May/ June 1986. Mar Ecol. Prog. Ser 38: 45-51

Bigelow, H. B. (1926). Plankton of the offshore waters of the Gulf of Maine. Bull. Bur. Fish., Wash. 40, Part II: 1-509

Bobrov, J. A. (1985). Fytoplankton, zizni uslovija je suchestvovaija v pelagiali Barentseva marja. Akad. Nauk. USSR, Apatity 1985: 99-126

Bodungen, B. v., Nöthig, E. M., Sui, Q. (1988). New production of phytoplankton and sedimentation during summer 1985 in the southeastern Weddell Sea. Comp. Biochem. Physiol. 90B: $475-487$

Bodungen, B. v., Smetacek, V., Tilzer, M. M., Zeitzschel, B. (1986). Primary production und sedimentation during spring in the Antarctic Peninsula region. Deep-Sea Res. 33: $177-194$

Cadée, G. C., Hegeman, J. (1986). Seasonal and annual variation of Phaeocystis pouchetii (Haptophyceae) in the western-most inlet of the Wadden Sea during the 1973 to 1985 period. Neth. J. Sea Res. 20: 29-36

Davidson, A. T., Marchant, H. J. (1987). Binding of manganese by Antarctic Phaeocystis pouchetii and the role of bacteria in its release. Mar Biol. 95: 481-487

Eberlein, K., Lean, M. T. Hammer, K. D., Hickel, W (1985).
Dissolved organic substances during a Phaeocystis pouchetii bloom in the German Bight (North Sea). Mar Biol. 89: 311-316

Eilertsen, H. C., Schei, B., Taasen, J. (1981). Investigations on the plankton community of Balsfjorden, northern Norway Sarsia 66: 129-141

Eilertsen, H. C., Tande, K., Hegseth, E. N. (1989). Potential of herbivorous copepods for regulating the spring phytoplankton bloom in the Barents Sea. Rapp. P.-v. Réun. Cons. int. Explor. Mer 188: 154-163

Estep, K. W., Nejstgaard, J. C., Skjoldal, H. R., Rey, F. (1990). Predation of copepods upon natural population of Phaeocystis pouchetii as a function of the physiological state of the prey. Mar. Ecol. Prog. Ser. (in press)

Føyn, L., Magnussen, M., Seglem, K. (1981). Automatisk analyse av næringsalter med 'on-line' databehandling. En presentasjon av oppbyggning og virkemåte av systemet $i$ bruk på Havforskningsinstituttets båter og i laboratoriet. Fisken Hav., Ser. B No. 4: 1-40

Frost, B. W., Laury, M. R., Hasset, R. P. (1983). Feeding behaviour of large calanoid copepods Neocalanus cristatus and $N$. plumchrus from the subarctic Pacific Ocean. DeepSea Res. 30: 1-13

Gieskes, W. W. C., Kraay, G. W. (1977). Primary production and consumption of organic matter in the southern North Sea during the spring bloom of 1975 . Neth. J. Sea Res. 11: 146-167

Gran, H. H. (1902). Das Plankton des Norwegischen Nordmeeres. Rep. Norw. Fish. Mar Inv. 2 (5): 1-222

Guillard, R. R. L., Hellebust, J. A. (1971). Growth and the production of extracellular substances by two strains of Phaeocystis pouchetii. J. Phycol. 7: 330-338

Haug, A., Myklestad, S., Sakshaug, E. (1973). Studies of the phytoplankton ecology of the Trondheimsfjord. I. The chemical composition of phytoplankton populations. J. exp. mar Biol. Ecol. 11: 15-26

Hegseth, E. N. (1982). Chemical and species composition of the phytoplankton during the first spring bloom in Trondheimsfjorden, 1975. Sarsia 67: 131-141

Holm-Hansen, O., Lorenzen, C. J., Holmes, R. W., Strickland J. D. H. (1965). Fluorometric determination of chlorophyll. J. Cons. perm. int. Explor. Mer 30: 3-15

Huntley, M., Tande, K., Eilertsen, H. C. (1987). On the trophic fate of Phaeocystis pouchetii (Hariot). II. Grazing rates of Calanus hyperboreus (Kroyer) on diatoms and different size categories of Phaeocystis pouchetii. J. exp. mar Biol. Ecol. 110: 197-212

Jackson, C. A. (1990). A model of the formation of marine algal flocs by physical coagulation processes. Deep Sea Res. (in press)

Jeffrey, S. M., Wright, S. W. (1987). A new spectrally distinct component in preparations of chlorophyll $c$ from the microalga Emiliana huxleyi (Prymnesiophyte), Biochim. Biophys. Acta 894: 180-188

Joiris, C., Billen, G., Lancelot, C., Daro, M. H., Mommaerts, J. P., Bertels, A., Bossicort, M., Nijs, J., Hecq, J. H. (1982). A budget of carbon cycling in the Belgian coastal zone relative roles of zooplankton, bacterioplankton and benthos in the utilisation of primary production. Neth. J. Sea Res. 16: 260-275

Kashkin, N. I. (1963). Materials on the ecology of Phaeocystis pouchetii (Hariot) Lagerheim, 1893 (Chrysophyceae). I. Habitat and specification of biogeographical characteristics. Okeanologija Mosk. 3: 697-705

Lagerheim, G. (1896). Uber Phaeocystis pouchetii (Hariot) Lagerheim, eine Plankton-Flagellate. Övers. K. VetenskAkad. Förh. 4: 277-288 
Lancelot, C. (1983). Factors affecting the phytoplankton extracellular release in the Southern Bight of the North Sea. Mar Ecol. Prog. Ser 12: 115-121

Lancelot, C. (1984). Metabolic changes in Phaeocystis pouchetii (Hariot) Lagerheim during the spring bloom in Belgian waters. Estuar coast. Shelf Sci. 18: 593-600

Lancelot, C., Billen, G., Sournia, A., Weisse, T., Colijn, F., Veldhuis, M. J. W. Davies, A., Wassmann, P. (1987). Phaeocystis blooms and nutrient enrichment in the coastal zones of the North Sea. Ambio 16: 38-46

Lancelot, C., Mathot, S. (1985). Biochemical fractionation of primary production by phytoplankton in Belgian coastal waters during short- and long-term incubations with ${ }^{14} \mathrm{C}$ bicarbonate. II. Phaeocystis pouchetii in colonial populations. Mar. Biol. 86: 227-232

Lopez, M. D. G., Huntley, M. E., Syskes, P. F. (1988). Pigment destruction by Calanus pacificus: impact on estimation of water column fluxes. J. Plankton Res. 10: 715-734

Lutter, S., Taasen, J. P., Hopkins, C. C. E., Smetacek, V (1989). Phytoplankton dynamics and sedimentation processes during spring and summer in Balsfjord, northern Norway. Polar Biol. 10: 113-124

Mantoura, R. F. C., Llewellyn, C. A. (1983). The rapid determination of algal chlorophyll and carotenoid pigments and their degradation products in natural waters by reversephase high performance chromatography. Analytica chim. Acta 151: 297-314

Mantoura, R. F. C., Llewellyn, C. A. (1984). Trace enrichment of marine algal pigments for use with HPLC-diode array spectroscopy. J. High Resolution Chromatogr Communs 7: $632-635$

Martens, P. (1981). On Arcatia species in the northern Wadden Sea of Sylt. Kieler Meeresforsch., Sonderheft 5 . $153-163$

Martin, J. H., Knauer, G. A., Karl, D. M. (1987). VERTEX: carbon cycling in the northeast Pacific. Deep-Sea Res. 34: $267-285$

Nelson, J. R. (1989). Phytoplankton pigments in macrozooplankton feces: variability in carotenoid alterations. Mar. Ecol. Prog. Ser. 52: 129-144

Palmisano, A. C., SooHoo, J. B., SooHoo, S. L., Kottmeier, S. T. Craft, L., Sullivan, C. W. (1986). Photoadaptation in Phaeocystis pouchetii advected beneath annual sea ice in McMurdo Sound, Antarctica. J. Plankton Res. 38: 723-731

Peinert, R., Bathmann, U., Bodungen, B. v., Noji, T (1987). The impact of grazing on spring phytoplankton growth in the Norwegian current. In: Degens, E. T, Izdar, E. I. Honjo, S. (eds.) Particle flux in the ocean. Mitt. Geol. Paläont. Inst. Univ. Hamburg, SCOPE/UNEP Sonderband, Heft 62: 149-164

Peinert, R., Bodungen, B. v., Smetacek, V. (1989). Food web structure and loss rates. In: Berger, W. H., Smetacek, V S., Wefer, G. (eds.) Productivity of the ocean: present and past. John Wiley \& Sons, p. 35-48

Platt, T., Gallegos, C. L. (1980). Modelling the primary production. In. Primary productivity in the sea. Brookhaven Symp. Biol. 31: 339-362, Plenum Press, New York

Repeta, D., Gagosian, R. B. (1982). Carotenoid transformation in coastal waters. Nature, Lond. 295: 51-54

Rey, F., Loeng, H. (1985). The influence of ice and hydrographic conditions on the development of phytoplankton in the Barents Sea. In: Gray, J. S., Christiansen, M. E. (eds.) Marine biology of polar regions and effect of stress on marine organisms. John Wiley \& Sons, New York, p. $49-63$

Rey, F., Skjoldal, H. R., Slagstad, D. (1987). Primary production in relation to climatic changes in the Barents Sea. In
Loeng, $H$. (ed.) The effect of oceanographic conditions on distribution and population dynamics of commercial fish stocks in the Barents Sea. Proceedings of the third SovietNorwegian Symposium, Institute of Marine Research. Bergen, p. 29-46

Roy, S., Harris, R. P., Poulet, S. A. (1989). Inefficient feeding by Calanus hegolandicus and Temora longicornis on Coscinodiscus wailesii: quantitative estimation using chlorophyll-type pigments and effects on dissolved free amino-acids. Mar. Ecol. Prog. Ser. 52: 145-153

Sakshaug, E. (1972). Phytoplankton investigations in Trondheimsfjord, 1963-1966. K. norske Vidensk. Selsk. Skr. 1: $1-56$

Sakshaug, E., Holm-Hansen, O. (1984). Factor governing the pelagic production in Polar Oceans. In: Holm-Hansen, $O$., Bolis, L., Gilles, R. G. (eds.) Marine phytoplankton and productivity. Lecture notes on coastal and estuarine studies No. 8. Springer Verlag, New York, p. 1-18

Sargent, J. R., Eilertsen, H. C., Falk-Pettersen, S., Taasen, J. P. (1985). Carbon assimilation and lipid production in phytoplankton in northern Norwegian fjords. Mar. Biol. 85: $106-116$

Savage, R. E. (1932). Phaeocystis and herring shoals J. Ecol. 20: $326-340$

Schnack, S. B., Smetacek, V., Bodungen, B. v., Stegman, P (1984). Utilisation of phytoplankton by copepods in Antarctic waters during spring. In: Gray, J. S., Christensen, M. E. (eds.) Marine biology of polar regions and effects of stress on marine organisms. John Wiley \& Sons, New York, p. 65-81

Sieburth, J. McN. (1979). Sea-microbes. Oxford University Press, New York

Skjoldal, H. R., Hassel, A., Rey F., Loeng, H. (1987). Spring phytoplankton development and zooplankton reproduction in the central Barents Sea in the period 1979-1984. In: Loeng, H. (ed.) The effect of oceanographic conditions on distribution and population dynamics of commercial fish stocks in the Barents Sea. Proceedings of the third SovietNorwegian Symposium, Institute of Marine Research, Bergen, p. 59-89

Skjoldal, H. R., Rey, F. (1989). Pelagic production and variability of the Barents Sea ecosystem. In: Sherman, K. Alexander, L. M. (eds.) Biomass and geography of large marine ecosystems. Westview Press, Boulder, Colorado, p $243-283$

Skreslett, S. (1988). Buoyancy in Phaeocystis pouchetii (Hariot) Lagerheim. J. exp. mar Biol. Ecol. 119: 157-166

Smayda. T (1.973). The growth of Skeletonema costatum during a winter-spring bloom in Narragansett Bay, R. I Norw J. Bot. 20: 219-247

Smetacek, V (1985). Role of sinking in diatom life-history cycles. ecological, evolutionary and geological significance. Mar. Biol. 84: 239-251

Tande, K. S., Bamstedt, U. (1985). Grazing rates of the copepods Calanus glacialis and C. finmarchicus in arctic waters of the Barents Sea. Mar. Biol. 87: 251-258

Tande, K. S., Bamstedt, U. (1987). On the trophic fate of Phaeocystis pouchetii. I. Copepod feeding rates on solitary cells and colonies of $P$. pouchetii. Sarsia: 72 : 313-320

Toggweller, J. R. (1989). Is the downward DOM flux important in carbon transport? In: Berger, W. H., Smetacek, V S. Wefer, G. (eds.) Productrvity of the ocean: present and past. John Wiley and Sons, p. 65-83

Vaqué, D., Duarte, C. M. Marrasé, C. (1989). Phytoplankton colonisation by bactena: encounter probability as a limiting factor Mar. Ecol. Prog. Ser. 54: 137-140

Veldhuis, M. J. W., Admiraal. W (1985). Transfer of photo- 
synthetic products in gelatinous colonies of Phaeocystis pouchetii (Haptophyceae) and its effect on the measurement of excretion rate. Mar Ecol. Prog. Ser 26: 301-304

Veldhuis, M. J. W., Colijn, F., Venekamp, A. H. (1986). The spring bloom of Phaeocystis pouchetii (Haptophyceae) in Dutch coastal water Neth. J. Sea Res. 20: 37-48

Verity, P. G., Villareal, T. A., Smayda, T J. (1988). Ecological investigations of blooms of colonial Phaeocystis pouchetii. I. Abundance, biochemical composition and metabolic rates. J. Plankton Res. 10: 219-248

Vernet, M. Lorenzen, C. J. (1987). The relative abundance of phenophorbide $a$ and pheophytin $a$ in temperate marine waters. Limnol. Oceanogr. 32: 352-358

Wang, R., Conover, R. J. (1986). Dynamics of gut pigment in the copepod Temora longicornis and the determination of in situ grazing rates. Limnol. Oceanogr. 31: 867-877

Wassmann, P. (1984). Sedimentation of organic matter in five

This article was submitted to the editor
west-Norwegian fjords. Ph.D. thesis, University of Bergen, Norway

Wassmann, P. (1989). Sedimentation of organic matter and silicate from the euphotic zone of the Barents Sea. Rapp. P.-v. Réun. Cons. int. Explor Mer 188: 108-114

Weisse, $T$ (1983). Feeding of calanoid copepods in relation to Phaeocystis pouchetii blooms in the German Wadden Sea are off Sylt. Mar Biol. 74: 87-94

Wright, S. W., Shearer, J. D. (1984). Rapid extraction and highperformance liquid chromatography of chlorophylls and carotenoids from marine phytoplankton. J. Chromatogr. 294: 281-295

Wright, S. W., Jeffrey, S. W. (1987). Fucoxanthin pigment markers of marine phytoplankton analysed by HPLC and HPTLC. Mar Ecol. Prog. Ser. 38: 259-266

Zenkievitch, L. A. (1963). Biology of the seas of the USSR. George Allen and Unwin Ltd., London

Manuscript first received: January 3, 1990

Revised version accepted: June 19, 1990 